\title{
Training Needs Assessment of Technical Skills in Managers of Tehran Electricity Distribution Company
}

\author{
Amir Hasan Koohi ${ }^{1,2}$, Fatemeh Ghandali ${ }^{3}$, Hasan Dehghan ${ }^{3} \&$ Najme Ghandali ${ }^{3}$ \\ ${ }^{1}$ Educational Administration, Garmsar Branch, Islamic Azad University, Garmsar, Iran \\ ${ }^{2}$ Farhangian University (Zeynabieh), Pishva, Iran \\ ${ }^{3}$ Ministry of Education (Office of Varamin), Iran \\ Correspondence: Amir Hasan Koohi, PhD candidate in Educational administration, Garmsar branch, Islamic \\ Azad University, Garmsar, Iran, Lecturer (invited teacher) at Farhangian University (Zeynabieh), Pishva, Iran. \\ E-mail: amirk1015@yahoo.com
}

\author{
Received: October 10, 2015 Accepted: November 15, 2015 Online Published: June 28, 2016 \\ doi:10.5539/ies.v9n7p161 URL: http://dx.doi.org/10.5539/ies.v9n7p161
}

\begin{abstract}
Current dissertation has been conducted in order to investigate and detect training needs of the mangers (top and middle) in Tehran Electricity Distribution Company. Research method is applied kind based on its purpose. Due to data collection method, this query is descriptive-survey type. Statistical population in this study is all of managers in Tehran Electricity Distribution Company in 2014 who are 144 men. Sample size has been determined 108 persons referring to the Morgan's table. To sample, multi-steps clustering method has been applied. Data collected using questionnaires. Questionnaire's validity has been obtained using comments by experts, guidance professor and consultant professors and its reliability was obtained via experimental implementation and calculating Cronbach's alpha which is equal to 0.93 Collected data were analyzed using descriptive statistical techniques (Mean, median, mode, standard deviation, skewness, elongation, minimum and maximum) and inferential statistical techniques (single group Chi-square test, independent t-test and Friedman's One-way Analysis of Variance and post hoc LSD test). Research findings imply that training needs assessment of technical skills in directors are: Technical issues, how to use computer and internet, Personnel and administrative matters, administrative rules and regulations, administrative correspondence principles and archive mechanisms, staff evaluation, appropriate use of funds, supervision, respectively. Also, it was manifested that there is a significant difference between training needs assessment of directors' technical skills based on their experience. No significant difference was observed between managers' technical skills based on their educational degree.
\end{abstract}

Keywords: training needs assessment, on-the-job training, technical skill

\section{Introduction}

In the modern developed world, continuous education and training of human force in the various organizations has an important and especial place. Addressing employees' training especially in managerial level with scheduled and precise planning can cause an enhancement in efficiency and effectiveness in each organization.

Due to vital and key role of managers and importance of their training, implementing logical; wisely and practical needs assessment prevents wasting a great deal of invest such as budget, facilities and time in a massive level. Moreover, it performs required training proportionated with the real needs. Start point and initial step in each training schedule is to clarify training needs which has a very important role in suitable designing of training courses and its effectiveness. It can be articulated that in reformation and training process, there is no duty more important than determining training needs and meeting these needs by proper training. Present shortcomings and lack of consistency and adaptability of implemented training courses with needs of these people will lead proposing questions.

\subsection{Research Necessity and Importance}

Various organizations and institutions in each society are generally formed based on certain demands and are developed. That's why; goals of each institution are a symptom of needs or specific needs which are critical for social survival. Developments have been emerged under the shadow of innovations and inventions have caused that organizations as a social institution are forced to cope and work in harmony with the changes. 
Organizational structure will propel from traditional and simple form to the various kinds of specialized and complicated ones and their tasks and functions are always developed. Therefore, preparation for a certain profession requires spending much time and professional trainings (Fathi, 2004, p. 58).

Each organization needs experienced and trained people to do its mission. If current employees' abilities were responsive to this need, employees' training would not necessary more. If it is not as this, it will be necessary to promote level of their skills and adaptability. This possibility that a young person learns some skills and continues his/her work until about 40 years without any fundamental change is so weak or totally improbable. In a society which is developing, not only employees' training is so desirable, but also it is a process in which each organization considers some resources for that in order to have efficient and intelligent human force.

No one can claim which is needless of acquisition of knowledge and skill, just with spending courses or lessons which have passed. Technology and science changes in today's world are so rapid that some people believe knowledge is efficient for them until 5 years. Each organization in its training and human force scheduling considers some orientations and emphasizes. Thus, they can make some changes in regard with employees' behavior modification and provide cause of organization's promotion (Haji-Yousefi, 2004, p. 65).

Managers by exploiting updated information can take and implement applicable and scientific policies tailored to condition and facilities and developments of their work environment and by applying available processed information, they respond different demands of their units such as planning, controlling, financing, qualification etc. They also approach work method optimization and efficiency enhancement (Bastani, 2002, p. 147).

In the modern developed world, permanent education and training of human force in the various organizations has an important and especial place. Addressing employees' training especially in managerial level with scheduled and accurate planning can cause enhancement in efficiency and effectiveness in each organization (Fathi, 2004, p. 168).

Today, human resource reformation and training is considered as one of the primary strategies to achieve human capital and positive consistency with change condition as 2 competitive advantages of organizations. Accordingly, its strategic importance and place has been appeared in organization's development and survival. It is transparent this activity like other organizational activities necessitates underlying and corrective planning. In this regard, determining training needs has been proposed as the first step in on-the-job training schedule. If it was properly sketched and implemented, it would be a fundamental and important measure for effectiveness of on-the-job training function and subsequently employees' productivity (Abbas-Zadegan and Tork-Zade, 1998, p. 14).

In organizational view, change is known as a transformation in the organization in order to provide the possibility to continue activity or its survival with respect to environmental condition. Human resource training and reformation in this condition in which its main features are complexity, diversity and rapid development, is referred as the chief guideline (Abbas-Zadegan \& Tork-Zade, 2000, p. 87).

What is separating modern knowledge from traditional training is to change attitude toward training issue, from training in a specific time domain to continuous training along the life. Today, employees' training is not limited to the educations given to the people at the beginning of their work, because staffs' continuous training is necessity with respect to environmental fast changes (Abtehi, 1867, p. 74).

With regard to vital and key role of managers and importance of their training, implementing logic; wisely and practical needs assessment prevents from wasting a great deal of invest such as budget, facilities and time in a vast level. Moreover, it performs required training proportionated with the real needs. Start point and initial step in each training schedule is to specify training needs which have a very important role in suitable designing of training courses and its effectiveness. It can be expressed that in reformation and training process, there is no task except determining needs (Alagheband, 2007, p. 69).

Classifying managers' skills into technical, human and cognitive skills and distinguishing between them will lead to facilitation in analysis; recognition; studying and investigating them. This doesn't mean that they are completely separable, but also these skills in different situations and in action are entirely blended. It can't be mentioned that when each skill is started and terminated and another skill is processed.

Of course, skills classification gives us this possibility that in the cases that for example a manager in one of the skills is weakened, it is specifically trained to resolve that. Besides interdependence and interconnectedness of these skills, it can be mentioned that rate of need to aforementioned skills by managers in different levels is variable. That's why low level managers need more technical skills while middle and top managers need less technical skill and instead require more cognitive skill. 
Benefits and objectives of conducting scientific and relevant researches in regard with identifying and measuring training needs and thereby practical application of derived results is that in designing training courses needed for employees and managers, undergoing attempts can be oriented. By proper guidance towards targets to meet the educational needs and provide the necessary training, we can step toward reformation and updating managers. In order to reach predetermined educational goals, for each training; it is needed to design and formulate educational content in advance which is not possible except doing scientific needs assessment and detecting them.

Hence, due to retraining importance and its role in promoting managers' performance and consequently increase in efficiency and effectiveness in managers, researcher decided to conduct this dissertation in directors of Tehran Electricity Distribution Company to detect their training needs and by proposing required training pattern, he tends to meet these training needs.

\subsection{Research Questions}

In which extent, managers of Tehran Electricity Distribution Company have hand on technical skills and in which areas, they have weakness and demand? According to what aforementioned in this query, the primary question is to inspect training needs of the mangers in Tehran Electricity Distribution Company which is split into 3 secondary questions:

1) What kinds of needs do mangers in Tehran Electricity Distribution Company have, respectively?

2) Is there any relation between managers' experience and their needs to training?

3) Is there any relation between managers' educational degree and their needs to training?

\section{Literature Review}

Diverse researches have directly or indirectly measured managers' training needs such as the following ones: Moradi (1994) came to this conclusion that managers need training in the contexts such as staff affairs management, psychology and consultant principles, educational planning, management methods and familiarity with regulations and laws and also Shahab (1999) found that managers requires training in the field such as job safety, delegation and educational technology, respectively. Soleimani (2000) in his dissertation implies that middle managers don't have triple skills, technical, human and cognitive and there is no significant difference between male and female managers in terms of having cognitive and technical skills.

Various researches done in national and international levels indicate that managers in many of managerial skills and contexts still don't have knowledge, information and required skills and they must be trained. Researches done by Ansari (2000), Arkani (2002), Soleimani (2000), Shahab (2008), Moradi (1994), Khodadai (2001), Shafiei (2002), Mohammadi (2003), Zarafshani and Beigi (2008) confirm training needs of managers.

Existed shortcomings and lack of consistency and adaptability of implemented training courses with needs of these people will lead proposing questions such as:

In which extent, managers of Tehran Electricity Distribution Company have hand on technical skills and in which areas, they have weakness and demand?

\section{Definitions}

Skill term refers to the abilities which are not necessarily internal, but they are prone to fostered. It especially reflects in how to do task, not only in his/her potential abilities.

Technical skill: That is wisdom and ability to do specific duties which requires proficiency in the use of special tools and techniques and practical competence in behavior and activity. Technical skills are obtained via acquiring internship and experience.

Manager: Someone who due to position in his/her workplace applies scientific principles and findings and technical skills artistically and comply with ethical norms; solve problems and gain an especial purpose

Technical skill: In this dissertation, it is technical issues, how to use computer and internet, personnel and administrative matters, administrative rules and regulations, administrative correspondence principles and archive mechanisms, staff evaluation, appropriate use of funds, supervision which are measured by Self-administrated questionnaire.

Technical skill is so vital in the organization especially in low levels and operational middle managers. The more movement from operational levels to the top and middle levels, technical skill is paled and at the top of the managerial pyramid, managers might be found that despite having low technical skill, due to this issue that their subordinates don't have enough technical skills, they are able to do their tasks and responsibilities appropriately 
(Alagheband, 2007, p. 93).

Technical skill means intelligence and ability to do specific tasks which requires proficiency in the use of special instruments and techniques and practical competence in behavior and activity. Technical skills are obtained via acquiring internship and experience. Managers usually learn these skills during training courses or internship such as knowledge and techniques and scheduling methods, budgeting, control and accounting, financial affairs and personnel affairs. Technical skills include knowledge and dexterity and expertise in activities related to methodologies, comprehensiveness and way of doing things. That's why; skill encompasses specific tools and techniques (Tousi, 2007, p. 136).

In the researches have been done abroad, results show that managers in the context of human skills such as building a better communication with personnel, human relationships and also skills related to financial affairs and accounting and also administrative reporting, require training. For example, researches done by Simon (2008) and Papa (2009) can be pointed.

\subsection{Population and Sampling}

Statistical population in this study is all of managers in Tehran Electricity Distribution Company in 2014 who are 144 men. Sample size has been determined 108 people referring to the Morgan's table. To sample, multi-steps clustering method has been applied.

\subsection{Research Method}

Type of research is applied kind based on its purpose. Due to data collection method, this query is descriptive-survey type.

\subsection{Data Collecting Tool}

Data collecting tool is a questionnaire. This questionnaire has been regulated in 2 parts in which the first part is related to general information about respondents such as age, educational and managerial experience, field, educational degree and passed training courses and in the second part is related to data collection. A questionnaire applied here is self-administrated one and responses are ranged in 5-points Likert scale. Several copies of the questionnaire to determine the validity have been provided for a number of experts and they were asked to express their corrective opinions about this questionnaire. After receiving remarks and modifying questionnaire and due to changes created in the questionnaire, its validity was inspected via guidance and consultant professors and was contently verified.

To determine reliability of mentioned questionnaire also, 30 managers (Out of main sample of respondents) were asked to respond questions and after eliciting data, Cronbach's alpha coefficient was calculated. Results obtained from Alpha coefficient have been displayed in the following table.

Table 1. Questionnaire's reliability coefficient

\begin{tabular}{ccc}
\hline Row & Indices & Reliability coefficient \\
\hline 1 & Technical skills & 0.93 \\
\hline
\end{tabular}

\section{Statistical Analysis Method}

In this dissertation, for statistical inspection and analysis of obtained data, descriptive and inferential statistical methods have been exploited. In descriptive analysis, data collected by indices of descriptive statistic such as mean, median, mode, standard deviation, skewness, elongation, minimum and maximum were summarized and categorized and data analysis was done using inferential statistical methods including single group Chi-square test, independent t-test and Friedman's One-way Analysis of Variance and post hoc LSD tests.

\section{Data Analysis}

After illustrating data via descriptive analysis and data analysis to response research main question that is: what are the training needs of managers based on technical skills, respectively? By calculating chi-square and results obtained from Friedman test, it was specified that training needs of managers' technical skills are obtained as the following. 
Table 2. Mean, median, mode, standard deviation, skewness, elongation, minimum and maximum of research variables

\begin{tabular}{lccccccccc}
\hline $\begin{array}{l}\text { Research } \\
\text { variables }\end{array}$ & Number & Mean & Median & Mode & $\begin{array}{l}\text { Standard } \\
\text { deviation }\end{array}$ & Skewness & Elongation & Minimum & Maximum \\
\hline $\begin{array}{l}\text { Technical } \\
\text { skill }\end{array}$ & 108 & 3.54 & 3.58 & 3.58 & 0.66 & -0.361 & -0.141 & 1.83 & 4.92 \\
\hline
\end{tabular}

- Technical skill

Domain of scores in studied group is between 1.83 and 4.92. Standard deviation of distribution is equal to 0.66 . Distribution mean was calculated equal to 3.54 . Skewness index is equal to -0.361 which implies that distribution in ratio with normal distribution is toward left. Elongation index of distribution is equal to -0.141 and reflects that elongation is shorter than normal distribution.

\subsection{What Are the Needs of Directors in Tehran Electricity Distribution Company in Terms of Technical Skill,} Respectively?

Table 3. Prioritizing training needs assessment of technical skills

\begin{tabular}{ccc}
\hline Prioritization & Ranks' mean & Technical skill indices \\
\hline First priority & 5.11 & Technical issues \\
Second priority & 5.18 & How to use computer and internet \\
Third priority & 5.26 & Administrative and personnel affairs \\
Fourth priority & 5.89 & Administrative rules and regulations \\
Fifth priority & 6.49 & correspondence principles and archive mechanisms \\
Sixth priority & 6.67 & staff evaluation \\
Seventh priority & 6.79 & appropriate use of funds \\
Eighth priority & 7.76 & supervision \\
\hline
\end{tabular}

Table 4. Friedman test

\begin{tabular}{cc}
\hline Number & 108 \\
Chi-square test & 245.748 \\
Freedom degree & 24.64 \\
Significance level & 0.000 \\
\hline
\end{tabular}

Calculated chi-square in Friedman test (245.748) with freedom degree (11) in significance level (0.01) is higher than table's chi-square (24.64). Therefore, priority of calculated means which have been exhibited in table (4-18) is significant.

\subsection{Is There Any Relationship Between Managers' Experience and Their Needs to Training?}

To compare directors 'opinion in 4 groups having management experience, 1 to 5 years, 6 o 10 years, 11 to 15 years and more than 16 years, one way variance analysis test has been used. Summary of calculations has been reflected in Tables $4 \& 5$. 
Table 5. Summary of one way variance analysis to compare mean of scores of 3 management skills among managers having different management experience

\begin{tabular}{ccccccc}
\hline $\begin{array}{c}\text { Management } \\
\text { skill }\end{array}$ & $\begin{array}{c}\text { Changing } \\
\text { resource }\end{array}$ & $\begin{array}{c}\text { Sum of } \\
\text { squares }\end{array}$ & $\begin{array}{c}\text { Freedom } \\
\text { degree }\end{array}$ & $\begin{array}{c}\text { Mean of } \\
\text { squares }\end{array}$ & F test & $\begin{array}{c}\text { Significance } \\
\text { level }\end{array}$ \\
\hline \multirow{3}{*}{ Technical skill } & Within group & 3.911 & 3 & 1.304 & 3.040 & \\
& Intergroup & 93.906 & 219 & 0.429 & & 0.030 \\
& Sum & 97.817 & 222 & & & \\
\hline
\end{tabular}

Technical skill: Due to this issue that calculated F (3.040) in significance level (0.05) is higher than Table's critical $\mathrm{F}$ (2.65), thus $\mathrm{H}_{0}$ is rejected. Therefore, it is concluded that there is a significant difference between means of 4 groups in the sense of training needs assessment of technical skill in viewpoint of managers having different management experience. Also, calculated means in managers having management experience more than 16 years is 3.52 ; in managers having management experience 11 to 15 years is equal to 3.49 ; in managers having management experience 6 to 10 years is equal to 3.39 and in managers having management experience 1 to 5 years is equal to 3.23 .

With regard to this fact that there was a significant difference in technical skill between managers having different work experience, consequently, a post hoc LSD test has been used.

Table 6. Results of post hoc LSD test

\begin{tabular}{ccccc}
\hline Experience (A) & Experience (B) & Mean difference & Standard error & Significance level \\
\hline \multirow{2}{*}{ 1 to 5 years } & 11 to 15 years & -0.2763 & 0.11 & 0.022 \\
& 16 years or higher & -0.3586 & 0.14 & 0.012
\end{tabular}

LSD test shows that there is a significant difference between managers having 1 to 5 work experience and 11 to 15 work experience. Mean of managers having 11 to 15 work experience is more than mean of managers having 1 to 5 years work experience. Also, there is a significant difference between managers having 1 to 5 work experience and more than 16 year work experience. Mean of managers having more than 16 year work experience is more than mean of managers having 1 to 5 years work experience.

\subsection{Is There Any Relation Between Managers' Educational Degree and Their Needs to Training?}

To compare managers' comments in 3 groups of managers having associates'; bachelor's and master's degree, One way variance analysis test has been used. Summary of calculations have been reflected in Table 6.

$$
\left\{\begin{array}{l}
H o=\mu 1=\mu 2=\mu 3 \\
H 1=\mu 1 \neq \mu 2 \neq \mu 3
\end{array}\right.
$$

Table 7. Mean and standard deviation of needs assessment score of3 management skills among managers having different educational degree

\begin{tabular}{cccccc}
\hline Management skill & Educational degree & Number & Mean & Standard deviation & Standard error \\
\hline \multirow{4}{*}{ Technical skill } & Associate's degree & 65 & 3.30 & 0.78 & 0.15 \\
& Bachelor's degree & 25 & 3.52 & 0.65 & 0.04 \\
& Master's degree & 18 & 3.91 & 0.36 & 0.07 \\
& Sum & 108 & 3.54 & 0.66 & 0.04 \\
\hline
\end{tabular}


Table 8. Summary of one way variance analysis to compare mean of scores of 3 management skills among managers having different educational degree

\begin{tabular}{ccccccc}
\hline $\begin{array}{c}\text { Management } \\
\text { skill }\end{array}$ & $\begin{array}{c}\text { Changing } \\
\text { resource }\end{array}$ & $\begin{array}{c}\text { Sum of } \\
\text { squares }\end{array}$ & $\begin{array}{c}\text { Freedom } \\
\text { degree }\end{array}$ & $\begin{array}{c}\text { Mean of } \\
\text { squares }\end{array}$ & F test & $\begin{array}{c}\text { Significance } \\
\text { level }\end{array}$ \\
\hline \multirow{3}{*}{ Technical skill } & Within group & 4.835 & 2 & 2.418 & 5.720 & \\
& Intergroup & 92.982 & 220 & 0.423 & & 0.004 \\
& Sum & 97.817 & 222 & & & \\
\hline
\end{tabular}

Technical skill: Due to this issue that calculated F (5.720) in significance level (0.01) is higher than Table's critical $\mathrm{F}$ (4.71), thus $\mathrm{H}_{0}$ is rejected. Therefore, it is concluded that there is a significant difference between means of 3 groups in the sense of training needs assessment of technical skill in viewpoint of managers having different educational degree. Also, calculated means in managers having master's degree is 3.91; bachelor's degree is 3.52 and associate's degree is equal to 3.30 .

(Total index): Because calculated F (9.85) in significance level (0.01) is higher than Table's critical F (24.71), thus $\mathrm{H}_{0}$ is rejected. Therefore, it is concluded that there is a significant difference between means of 3 groups in the case of training needs assessment of management technical skill in viewpoint of managers having different educational degree. Also, calculated means in managers having master's degree is 3.81; bachelor's degree is 3.31 and associate's degree is equal to 3.16. Subsequently, there was a significant difference between three skills of management and total index among mangers having different educational degree. Thus, post hoc LSD test has been used.

\subsection{LSD Test for Technical Skill}

Table 9. Results of post hoc LSD tests

\begin{tabular}{ccccc}
\hline Educational degree (A) & Educational degree (B) & Mean difference & Standard error & Significance level \\
\hline Master's degree & Associate's degree & 0.61 & 0.18 & 0.001 \\
& Bachelor's degree & 0.39 & 0.14 & 0.006 \\
\hline
\end{tabular}

LSD test implies that there is a significant difference between managers having master's degree and managers having bachelor's and associate's degree and mean of managers having master's degree is higher than mean of managers having bachelor's and associate's degree.

\subsection{LSD Test for Total Index}

Table 10. Results of post hoc LSD tests

\begin{tabular}{ccccc}
\hline Educational degree (A) & Educational degree (B) & Mean difference & Standard error & Significance level \\
\hline \multirow{2}{*}{ Master's degree } & Associate's degree & 0.64 & 0.16 & 0.000 \\
& Bachelor's degree & 0.49 & 0.12 & 0.000 \\
\hline
\end{tabular}

LSD test reflects that that there is a significant difference between managers having master's degree and managers having bachelor's and associate's degree and mean of managers having master's degree is higher than mean of managers having bachelor's and associate's degree

To study the third question in this paper called "Is there any relation between managers' educational degree and their needs to training? It was specified that there is a significant relationship between mean of 3 groups (bachelor's; master's and associate's degree) about needs assessment of technical skill in viewpoint of managers having different educational degree. Mean of managers having master's degree is higher than mean of bachelor's and associate's degree. 


\section{Summary and Discussion}

All of management jobs require applying skills. Although, in doing some tasks, three skills are necessary and they are compliment, despite of this fact, their relative value is different in different levels of management. Managers in supervision level need considerable technical skill, because their duties mostly cause to lead or teach their subordinates. In contrast, mangers in high levels of organization don't need technical skills that much, but also duty of decision making, scheduling and organizing will lead to be equipped to the significant cognitive skill. Human skills are always prerequisite for managers in all levels of management because all of them, regardless of kind of task or status and responsibility level, are dealing with people and to attract cooperation and effectiveness on their behavior, they have to be equipped by human skills. That's why, today in management, addressing human skills have been taken an especial priority.

Various organization by holding short-term and long-term training courses and much costs, have stepped toward promoting knowledge and skill level and eventually enhancement in performance, but in most of cases, due to lack of scientific; logic and precise needs assessment; applying different tastes and lack of consistency between educational content and demand, in several cases obtained results weren't much eye-catching or it is not adapted with predetermined educational goals and destinations. That's why, researcher intends to detect training needs of Tehran educational mangers conducting current query.

In this dissertation, it has been attempted to review records relevant to identifying managers' educational needs based on technical skills. In this sense, by recognizing demand cases, in addition to resolving defects, skills and efficiency and effectiveness of managers will be promoted.

To get familiar with conceptions and factors affecting on needs assessment precisely, managers' needs assessment has been done by centralizing the following issues:

1) Expressing concepts and viewpoints about management definition and its necessity

2) Defining management and its necessity

3) Explaining and expressing technical skill required for managers

\section{Recommendations Inferred from the Research}

1) Due to compulsion and importance of training and taking advantage of world modern techniques and sciences, authorities have to motivate employees, mangers and experts to learn better and more in job areas.

2) Since, training needs assessment is diversified and transformed by marching time, it is recommended to always continue conducting needs assessment projects in different periods and be applied as a prerequisite for planning and designing educational courses.

3) Needs assessment has to be primordially and not temporarily done based on modern and scientific methods and principles. Executive and educational authorities are expected to provide required facilities and research contexts especially communications and facilities relevant to exchanging world modern information to be applied by managers.

4) Order of presented priorities and needs are complied with sketching and formulating training courses which facilitates achieving educational considered and formulated targets

\section{References}

Abbaszadegan, M., \& Turk-Zade, J. (2000). Educational need assessment in organizations. Tehran, Enteshar Inc.

Abtehi, H. (1987). Human resource training and development and staff training problem. Journal of Public Administration, Tehran.

Alagheband, A. (1996). Public Management. Tehran, Ravan publication.

Alagheband, A. (2007). Educational Management. Tehran, Ravan publication.

Alagheband, A. (2007). Public Management. Tehran, Ravan publication.

Arkani-Far, A. (2002). Middle managers 'need assessment in Bojnoord and proposing recommended on-the-job training model to enhance the managers' skills (Unpublished master thesis). Khorasan province management and planning organization.

Bastani, P. M. M. (2002). Presidents of schools and ICT. Tehran, school management growth, No 4.

Entesari, N. (2000). Need assessment of managers'technical, human and cognitive skills and provide a model for their on-the-job training (Unpublished master thesis). Tehran, Tehran University of Educational Sciences. 
Fathi, K. (2004). An introduction to planning staff on-the-job training. Tehran. Aizh publication.

Haji-Yousefi, M. (2004). Effect of on-the-job training on increase in employees' job skills level. Tavon Journal.

Khalvad, H. (1990). Education in administrative organizations. Tehran: Public Administration Training Centre.

Khodadadi-Nejad, P. (2002). Providing a model for the assessment of technical skills and management on-the-training in Tehran (Unpublished master's thesis). University of Psychology and Social Sciences, Islamic Azad University of Central Tehran.

Martin, G., \& Papa, R. (5001). Examining the Principal Preparation and Practice Gap. Principal, 11(3), 31-35.

Mohammadi, M. (2003). Educational needs assessment of secondary school presidents, area 2 in Zanjan City.

Moradi, N. (1994). Studying training needs of managers in Lorestan province (Unpublished master's thesis). Faculty of Psychology and Educational Sciences, Tehran University.

Rubaie-Mendejin, M. R. (1999). New approach to staff training and development of managers. Culture and cooperation Journal, 15.

Shafie-Touchahi, F. (2002). Need assessment of training needs of knowledge and work managers in Tehran and proposing training model for their management courses (Unpublished master's thesis). Faculty of Psychology and Social Sciences, Islamic Azad University of Central Tehran.

Shahab, A. A. (1999). Need assessment of managers in three courses (elementary, secondary and high school) in Ghochan Ministry of Education in order to increase their efficiency (Unpublished master's thesis). Islamic Azad University of Sari.

Soleimani, N. (2000). Needs assessment and proposing a recommended on-the-job training program to enhance the skills of high school principals in Isfahan province, research plan.

Tousi, M. A. (2007). Educational management and leadership. Tehran, Baztab publication.

Wildy, H., \& Clarke, S. (5001). Charting an Arid Landscape: The Preparation of Novice Primary Principals in Western Australia (EJ150111). School Leadership \& Management, 51(2), 113-113.

Zarafshani, K., \& Baygi, A. (5001). What Can a Borich Needs Assessment Model Tell Us about In-Service Training Needs of Faculty in a College of Agriculture? The Case of Iran, Journal of Agricultural Education and Extension, 3(1), 113-123.

\section{Copyrights}

Copyright for this article is retained by the author(s), with first publication rights granted to the journal.

This is an open-access article distributed under the terms and conditions of the Creative Commons Attribution license (http://creativecommons.org/licenses/by/3.0/). 